\title{
THÉRIAULT Joseph Yvon, Critique de l'américanité. Mémoire et démocratie au Québec
}

\section{Gilles Ferréol}

\section{(2) OpenEdition}

1 Journals

\section{Édition électronique}

URL : https://journals.openedition.org/remi/4026

DOI : $10.4000 /$ remi.4026

ISSN : $1777-5418$

Éditeur

Université de Poitiers

\section{Édition imprimée}

Date de publication : 1 mai 2004

Pagination : 207

ISBN : 2-911627-36-9

ISSN : 0765-0752

\section{Référence électronique}

Gilles Ferréol, «THÉRIAULT Joseph Yvon, Critique de l'américanité. Mémoire et démocratie au Québec », Revue européenne des migrations internationales [En ligne], vol. 20 - $\mathrm{n}^{\circ} 1$ | 2004, mis en ligne le 25 septembre 2005, consulté le 16 avril 2022. URL : http://journals.openedition.org/remi/4026 ; DOI : https://doi.org/10.4000/remi.4026

Ce document a été généré automatiquement le 16 avril 2022.

(c) Université de Poitiers 


\title{
THÉRIAULT Joseph Yvon, Critique de l'américanité. Mémoire et démocratie au Québec
}

\author{
Gilles Ferréol
}

\section{RÉFÉRENCE}

THÉRIAULT Joseph Yvon, Critique de l'américanité. Mémoire et démocratie au Québec, Montréal, Éd. Québec Amérique, 2002, 374 p. ISBN : 2760002926

1 Ce livre, confesse l'auteur, a une histoire, celle "d'un étonnement, voire d'un agacement, face à la généralisation de la référence à l'américanité pour décrire l'identité nouvelle des Québécois»(p. 11). Cette utilisation, est-il précisé (ibid.), est récente et «débute timidement au début des années 1970, principalement dans les milieux littéraires» (songeons, entre autres, aux romans de Jacques Godbout, de Jacques Poulin ou de Réjean Ducharme), pour s'affirmer pleinement une décennie plus tard. La frontière, dans cette optique, n'est pas qu'une simple expérience, elle est aussi reconstruction et invite à prendre ses distances avec le paradigme dominant d'une «nation victime, constamment humiliée et menacée » (p. 145).

2 Au-delà du banal constat géographique, un tel concept - à la fois «poubelle » et «fourre-tout» (p. 23) - met en exergue une appartenance spécifique, déjà présente dans les écrits d'un Jean Lemoigne, participe d'une trajectoire de réalignement tant politique que culturel vers les États-Unis et suscite un débat plus large touchant à l'interprétation de la modernité.

Deux grands questionnements méritent, sous cet angle, attention. Le premier, comme l'ont bien montré Ronald Rudin ou Jocelyn Létourneau, a trait au rapport au passé et à la mémoire; le second prolonge le précédent mais avec un prisme plus sociologique, centré sur les relations qu'entretiennent tradition et modernisme. Parmi les passages les plus intéressants, mentionnons ceux, relatifs au nationalisme et à l'ethnicité, au 
peuple et à la souveraineté, au " postrévisionnisme » et aux « jugements de valeur » (p. 209). La confrontation des thèses défendues par Lord Durham, Étienne Parent, LouisJoseph Papineau et, plus proches de nous, Henri Bourassa, Pierre Elliott Trudeau ou Gérard Bouchard, se révèle ici très judicieuse, de même que l'analyse critique de la problématique identitaire (p.120), de la société duplessiste (p. 206) ou de la " prétendue fascination de la souche » (p. 180).

4 Un ouvrage - au total - décapant, bien écrit et qui nous rappelle fort opportunément que, de nos jours encore, «le détour européen, l'un des héritages majeurs du Canada français, reste riche d'enseignements » (p. 117).

\section{AUTEURS}

\section{GILLES FERRÉOL}

Université de Poitiers, LARESCO-ICOTEM 